\title{
REDISCOVERY OF FUIRENA REPENS (CYPERACEAE), A RARE ENDEMIC OF THE MEXICAN HIGH PLATEAU
}

\author{
David J. Rosen ${ }^{1}$, Christopher S. Reid ${ }^{2}$, M. Socorro González Elizondo ${ }^{3}$ and \\ ROBERT KRAL ${ }^{4}$
}

\begin{abstract}
${ }^{1} \mathrm{~S}$. M. Tracy Herbarium, Department of Ecosystem Science \& Management, Texas A\&M University, College Station, Texas 77843-2138, U.S.A. txplants@yahoo.com

${ }^{2}$ Louisiana Natural Heritage Program, Louisiana Department of Wildlife and Fisheries, Baton Rouge, LA 70898, U.S.A. creid@wlf.louisiana.gob ${ }^{3}$ Instituto Politécnico Nacional, Centro Interdisciplinario de Investigación para el Desarrollo Integral Regional, Unidad Durango. Sigma s.n. Fraccionamiento 20 de Noviembre II, 34220 Durango, Durango, México. herbario_ciidir@yahoo.com.mx ${ }^{4}$ Botanical Research Institute of Texas, Fort Worth, TX 76102-4060, U.S.A.
\end{abstract}

\begin{abstract}
Fuirena repens was known for many years only from the Mexican state of San Luis Potosí, where it is documented by a few historical specimens. Recent field and herbarium studies have revealed two additional stations for this species in the states of Queretaro and most recently, Durango. We present a key to Mexican species of Fuirena and an updated description of $F$. repens based on the new collections. The few existing records suggest $F$. repens is rare and endemic to the Mexican High Plateau.
\end{abstract}

Key words: Cyperaceae, Durango, endemic, Fuirena, Mexico, Queretaro.

\section{RESUMEN}

Fuirena repens se conoció por más de un siglo únicamente de San Luis Potosí, documentada de unos pocos ejemplares históricos. En este trabajo se revelan dos localidades adicionales de la planta para los estados de Querétaro y de Durango; se presenta una clave para las especies mexicanas de Fuirena y una descripción de F. repens basada en la información obtenida de los nuevos materiales. Los pocos registros existentes parecen indicar que $F$. repens es un taxon raro, endémico a la Altiplanicie Mexicana.

Palabras clave: Cyperaceae, Durango, endemismo, Fuirena, México, Querétaro. 
Fuirena Rottb. (Cyperaceae) comprises over 30 species usually of wetland habitats in warm temperate to tropical regions worldwide (Kral, 1978, 2002). For Mexico, Kral (1978) treated five species: F. camptotricha C. Wright, F. incompleta Nees, F. repens Boeck., F. simplex Vahl, and F. umbellata Rottb. Later, F. robusta Kunth was recorded for the country by Adams (1994) and Espejo-Serna y LópezFerrari (1997), and a new species, F. stephani Ramos \& N. Diego, was described from a collection from Campeche (Ramos-Álvarez and Diego-Pérez, 2002). Fuirena repens was previously known from very few collections, all presumably near the type locality in San Luis Potosí (Kral, 1978). Herbarium work by Anton A. Reznicek and S. González revealed a more recent collection of F. repens from Queretaro and subsequent field work has led to collections of the same species from seepage wetlands in the Mexican High Plateau in Durango. The Durango plants were growing in clear shallow water on mucky substrate associated with Bidens sp., Cyperus spp., Eleocharis spp., Fimbristylis sp., F. incompleta var. obliterata Kral, Leersia hexandra, Potamogeton sp. and Rhynchospora sp. Based on our current knowledge, $F$. repens is a rare endemic of the Mexican High Plateau. The plants from Durango represent a bigger, copiously hirtellous variant. The following key and description modified from Kral (1978) reflects an updated concept of this species based on recent collections and field observations.

\section{Key to Fuirena in Mexico}

1. Perianth in part or solely of tepals bearing broad blades.

2. Perianth comprised of both bladed and bladeless tepals, the latter represented by bristles reaching at least to the middle of the stipe of the achene.

3. Larger leaf blades narrower than $1 \mathrm{~cm}$; outer perianth series comprised of retrorsely barbed bristles; petal blades rounded or emarginate at the apex, with a retrorsely barbed awn F. simplex

3. Larger leaf blades wider than $2 \mathrm{~cm}$; outer perianth series comprised of bristles or linear-fusiform elements, smooth; petal blades acute or acuminate at the apex, with a scabrous or antrorsely barbed awn.

4. Outer perianth series comprised of bristles F. robusta

4. Outer perianth series of perianth comprised of linear-fusiform elements, one of them broader in the middle and longer than the others 
2. Perianth comprised only of bladed tepals, (very reduced, tubercle or papillalike bristles may sometimes be located inward or outward from the bladed members).

5. Claw of petal blades crimped; robust plants with stout cormous rhizomes and culms at least $5 \mathrm{~mm}$ thick; inflorescence often diffuse, comprised of many glomerules of spikelets.

6. Mature petal blades flattish or thickened only marginally, over the nerves, and apically, the apex generally retuse-notched, from this notch arising a slender, coiled bristle ........................... F. umbellata

6. Mature petal blades with distal half tumid, inflated, the apex broadly conic or obtuse, papillose-scabrid, the bristle, if present, shorter, dorsal, subapical, erect or incurved .................F. camptotricha

5. Claw of petal blades straight; slender low plants from slender, diffusecreeping, ecormous, elongate rhizomes, the culms never as thick as 2 $\mathrm{mm}$; inflorescence usually a terminal cluster of sessile or subsessile spikelets F. repens

1. Perianth comprising only bristles or perianth essentially absent.

7. Perianth bristles usually 6 , subequal, most of them well exceeding the middle of the achene body .............................. F. incompleta var. incompleta

7. Perianth bristles absent or reduced to short, unequal lengths, rarely exceeding the middle of the achene body ............ F. incompleta var. obliterata

Fuirena repens Boeck. Bot. Jahrb. Syst. 7: 277. 1886. Type: Mexico, San Luis Potosí, 1879, J. G. Schaffner 196 (Holotype: B-presumably destroyed, Lectotype (designated by Kral, 1978 as neotype): NY; Isolectotypes: $\mathrm{C}, \mathrm{MICH})$.

Slender low perennial, rhizomes creeping, fleshy, slender but swollen at irregular intervals into narrowly fusiform thickened zones, white to pale reddish-brown, internodes frequently 1.3-2.3 cm long, often forking or 3-branched or producing compact, narrowly fusiform, several-noded rhizomatous offshoots, these developing apically into leafy shoots. Shoots erect, low, to $4.2(-5) \mathrm{dm}$, the lowermost part scaly, smooth, the leaves of midculm longest; sheaths tubular-cylindric, rather loosely investing the culms and often overlapping, multicostate, hirsute, the Iigular orifice scarious, oblique, ciliate, pale brown; larger leaf blades narrowly linear, ascending or spreading, to $19 \mathrm{~cm}$ long but usually much shorter, rarely broader than $6 \mathrm{~mm}$, attenuate from near the base to the slender apex, smooth to sparsely or copiously hirtellous with weak, 
translucent hairs, sparingly spreading-ciliate proximally. Culms smooth proximally, multicostate, with internodes becoming spreading hirtellous upward, terminating in a subcapitate cluster of (1-)3-7 spikelets subtended by 1-3 leaflike bracts, these shorter than to ca. three times the length of the spikelets, spreading to ascendent, hirtelloushirsute proximally, smooth to scabrid distally. Spikelets ovoid to lance-ovoid, greenish or olivaceous, the longest ca. $1 \mathrm{~cm}$ long. Fertile scales obovate, thin, ca. $2.5 \mathrm{~mm}$ long, the backs hispidulous and sparingly strigose, medially 3-nerved, these converging to form a spreading-ascending mucro to $2.5 \mathrm{~mm}$ long. Perianth of three bladed petals, the calyx bristles reduced to minute sharp-tipped tubercles; petals ca. 2-2.5 $\mathrm{mm}$ long, the claw ca. $0.4 \mathrm{~mm}$ long, the blade ovate, proximally flattish and triple-nerved, the distal 1/2 inflated and tapering into a slender, erect to incurved awn. Anthers ca. 2 $\mathrm{mm}$ long. Achene ca. $1.5 \mathrm{~mm}$ long altogether, the stipe shorter than to nearly as long as the sharply trigonous body, the stylar end slender elongate, slightly broadening and scaberulous-papillose distally; achene surface pale, minutely cancellate-punctate, the 3 edges smooth, wirelike, glassy.

Additional specimens examined: Mexico: Durango, Presa Santiago Bayacora, off of the road to Aserradero La Flor (Hwy. 115), $16.7 \mathrm{~km} \mathrm{~S}$ of the intersection of MX Hwy. 40 and MX Hwy. 45 in the City of Durango, elev. 1988 m, N 2352'35.7" W 104'40'29.7", 2 Oct. 2007, Rosen et al. 4519 (TAES, TEX, VDB); same date and locality, Reid 6329 (LSU); same date and locality, S. González et al. 7371 (CIIDIR, IEB, MEXU, MICH, SLPM); same date and locality, P. M. Peterson et al. 21239 (CIIDIR, US). San Luis Potosí, “ex convalli San Luis Potosí", 1877, J. G. Schaffner 567 (MEXU-2); San Rafael, S.L.P., 1877, J. G. Schaffner 567 (MEXU). Querétaro, mpio. La Cañada, Rancho El Pinalito, cerca de La Laborcilla, 2400 m, 14 Sept. 1990, S. Zamudio y E. Pérez C. 8107 (CIIDIR, IEB).

\section{ACKNOWLEDGEMENTS}

The first three authors thank colleagues Paul M. Peterson and Jeff Saarela for transportation, campfire songs, and companionship in the field. Funding for travel for Reid was provided by the Louisiana Department of Wildlife and Fisheries. Socorro González thanks to Comisión de Operación y Fomento de Actividades (COFAA) and Secretaría de Investigación y Posgrado of the Instituto Politécnico Nacional for research support. We greatly appreciate the suggestions provided by two anonymous reviewers, which helped to improve the manuscript. 


\section{LITERATURE CITED}

Adams, C. D. 1994. Fuirena (Cyperaceae). In: Davidse, G., M. Sousa y A. O. Chater (eds.). Flora Mesoamericana. Vol. 6. Universidad Nacional Autónoma de México-Missouri Botanical Garden-The Natural History Museum. London. pp. 450-452.

Espejo-Serna, A. y A. R. López-Ferrari. 1997. Las monocotiledóneas mexicanas. Una sinopsis florística. 1. Lista de referencia. Parte V. Cyperaceae. Universidad Autónoma Metropolitana-Comisión Nacional para el Conocimiento y Uso de la Biodiversidad. México, D.F. 98 pp.

Kral, R. 1978. A synopsis of Fuirena (Cyperaceae) for the Americas north of South America. Sida 7: 309-354.

Kral, R. 2002. Fuirena. In: Editorial Committee (ed.). Flora of North America, Vol. 23. Oxford Univ. Press. New York. pp. 32-37.

Ramos-Álvarez, C. H. y N. Diego-Pérez. 2002. Una especie nueva de Fuirena (Cyperaceae) del estado de Campeche, México. Acta Bot. Mex. 58: 51-55. 
